\title{
Message from the Chief Editor
}

W th great pleasure I am writing a few words for the new Journal of Kathmandu Medical College (JKMC) where I am serving as Chief Editor for the second term.

After serving for the journal of Nepal Medical Association (JNMA) and Nepal Paediatric Society as Editor I thought it was my duty to bring out a journal under Kathmandu University where I was affiliated to.

Moreover, with the opening of half a dozen Medical Colleges under Kathmandu University I and Prof. Dixit proposed to the Dean of Kathmandu University to help bring out a joint journal to pool the research activities from all these Medical Colleges and give them a platform to publish their data. Our proposal was readily accepted and we started the publication of KUMJ with an office set up at Kathmandu Medical College and me acting as Editor-in-Chief and Prof. Dixit as Consulting Editor.

Owing to the dedication and hard work of our editors at our office at Kathmandu Medical College, KUMJ was able to receive an indexed status in PubMed within a year of its publication. As a result, national and international research articles then started pouring in. The whole team of enthusiastic editors of KUMJ and their hard work not only managed to index KUMJ in PubMed but also got KUMJ affiliated to other international organizations related to scientific publication for example, COPE, NepJol, EMBASE, Elsevier etc.

After eight years of publication and thirty issues on its credit Kathmandu University decided to take over KUMJ. We readily gave up and KUMJ is currently being published by Kathmandu University School of Medical Sciences itself.
The History of Journal of Kathmandu Medical College (JKMC) is that it saw the day in the year 1999 as yearly publication when KMC was under the CIN (Charity International) management. As we were all so much absorbed and most of our time was invested in the management of KUMJ, We had to stop bringing out JKMC after publishing five issues.

As the management of KUMJ had been shifted to Kathmandu University, a group of young enthusiastic faculty members approached me to revive JKMC, and requested me to take the responsibility of Chief Editor, and I had no alternative than to accept the request. The point was as every Medical College has been bringing out their own journals in the recent years, why not to revive Journal of Kathmandu Medical College and resume its publication which had been left over.

Professor Hemang Dixit who has always been associated with me in this type of venture in the past readily accepted to help support me as member of editorial team and we both went ahead.

Here I am back second time as Chief Editor with a determination to make it as one of the best journals of this region with everybody's effort and support.

With a new look, JKMC is back in your hand and we promise you to come to your expectation and also make it an international indexed journal. However, for all this we need your whole hearted support and contribution in the future issues.

Happy writing and see you in the pages of JKMC.

Prof. M. R. Baral Chief Editor 